\title{
Adoption of yield-increasing technologies in poorly integrated crop output markets
}

\author{
Relwende Apollinaire Nikiema* \\ Department of Agricultural and Resource Economics, The University of Tokyo, Japan
}

Received: 28 July 2020

Revised: 15 December 2020

Accepted: 14 February 2021

\begin{abstract}
This paper analyzes the relationship between crop market integration and the use of modern inputs of farmers in developing countries. For this purpose, we used a large-scale household dataset collected in rural Burkina Faso. We found evidence that there is a negative association between the use of yield-increasing inputs by farmers and low crop market integration. An increase of the spatial price dispersion by $10 \%$ is significantly associated with a decrease in the probability of using modern inputs by 0.04 points and a decrease in the intensity of adoption by $12.5 \%$ approximately relative to the sample mean. Moreover, the results suggest that this association is stronger for farmers who previously adopted these inputs. Accompanying the promotion of modern inputs with market development measures can help increase its chance of success.
\end{abstract}

Keywords: market integration; modern inputs; economic return; Burkina Faso

JEL Classification Codes: C23, D4, Q12, Q16

\section{Introduction}

Why is the rate of adoption of modern inputs persistently low in developing countries?

Previous studies have investigated the supply-side constraints to technology adoption (AbdulHanan, 2016; Beaman et al., 2018; Croppenstedt et al., 2003). These studies assume implicitly that the adoption of modern inputs is always profitable, and that the crop markets are performing well. However, commodity markets in developing countries are not only disconnected from the international market, but they are also domestically fragmented in many cases (Baquedano \& Liefert, 2014; Bekkers et al., 2017). This may affect the profitability of yield-increasing technologies and therefore hinders the adoption of yield-increasing inputs (Gabre-Madhin et al., 2003).

The role of profitability in the decision to adopt yield-improving technologies is advocated in some recent works. For instance, Suri (2011) shows that individual comparative advantage as measured by the rate of return determines the decision to adopt while Michler et al (2018), found that high adoption is explained by economic gain through cost reduction rather than the farmer's comparative advantage. However, these studies are focused on physical output and the constraints

\footnotetext{
*Corresponding author. E-mail: apollinaire-nikiema@g.ecc.u-tokyo.ac.jp.

Citation: Nikiema, R. A. (2021) Adoption of yield-increasing technologies in poorly integrated crop output markets, Economics and Business Letters, 10(3), 319-330.
}

DOI: 10.17811/ebl.10.3.2021.319-330 
in accessing inputs. In so doing, they do not account for the change in the relative output price that follows the wide use of the modern inputs, neither do they explain farmers' year-to-year switching behavior from being adopters to non-adopters of modern inputs and vice-versa.

Furthermore, some previous researches have tackled the conceptual issues around the effects of crop market efficiency on the adoption of yield-increasing technologies by agricultural producers (Barrett, 2008; Cochrane, 1958; Gabre-Madhin et al., 2003; Hayami \& Herdt, 1977). However, none of them have provided empirical evidence. In this study, we attempt to fill this gap by analyzing how the integration of the crop market affects the farmers' decision to use modern inputs in Burkina Faso. Here, we posit and test the hypothesis that crop market low integration affects negatively farmers' decision to adopt yield increasing technologies.

\section{Methods}

\subsection{Theoretical framework}

This study is based on the strand of literature that investigates the conceptual issues around the fundamental problem of the negative price effects of technological change on agricultural producers (Cochrane, 1958; Hayami and Herdt,1977). Following Hayami and Herdt (1977), the distribution of the gains from technical change depends crucially on the price elasticity of demand for the product, which in turn depends heavily on how well integrated the local market is with broader national, regional, and global markets. Producers adopt new technologies because they reduce unit costs, thereby increasing productivity and output. But in the general equilibrium, when enough producers adopt the technology, the aggregate supply curve shifts, and prices fall too. This potentially leaves producers worse off than before if demand is sufficiently inelastic. Therefore, since most agricultural products exhibit highly inelastic demand, maintaining efficient market integration is that much more important to ensure producers benefit in the long run from technological change (Barrett, 2008).

Following Fackler and Goodwin (2001), market integration can be thought as a measure of the degree to which demand and supply shocks arising in one region are transmitted in another region. In this study, we focus on price differentials between two markets to explore market integration under the spatial equilibrium approach and its effect on smallholder farmers' technology adoption. The spatial equilibrium model can be summarized as follows (Judge and Takayama, 1971):

$$
p_{t}^{i}-p_{t}^{j} \leq \psi_{j \rightarrow i}
$$

where $p_{t}^{i}$ is the price of the good in the deficit market $i$ and $p_{t}^{j}$ price in the surplus market $j$ at time $t$ and $\psi_{j \rightarrow i}$ is the cost of trade from market $j$ to market $i$. The spatial equilibrium model stipulates that in an efficient market, the prices of a given good at two locations should not differ by no more than the transaction costs of trading the good between these locations. Otherwise, traders will engage in spatial arbitrage, which increases the price at the low-price market and reduces the price in the high-price market until the spatial equilibrium $p_{t}^{i}-p_{t}^{j}=\psi_{j \rightarrow i}$ is restored.

In a context of limited sales opportunities, due to missing or poorly functioning markets, the assumed equivalence between yields and economic returns may have led the literature astray. Adoption of modern inputs is a costly investment for rural farmers in developing countries. Farmers will invest in modern inputs if the marginal revenue from crop sales is at least equal to the marginal cost. However, in fragmented markets, small shifts in supply can affect local market prices (Burke et. al, 2017). Therefore, investments that increase production may result in lower crop prices, reducing the incentive to further invest in new technology (Karlan et al, 2015). 


\subsection{Empirical model}

The baseline specification is as follows:

$$
\begin{gathered}
\text { Adopt }_{\text {hit }}=\gamma M I_{i t-1}+\text { Province }_{i t-1}^{\prime} \theta_{1}+W_{t}^{\prime} \beta+X_{t}^{\prime} \theta_{2}+u_{i h}+\varepsilon_{i h t} \\
\text { Price_dispersion }_{i t-1}=\left|\ln \left(P_{i t-1}\right)-\ln \left(P_{r t-1}\right)\right| * 100
\end{gathered}
$$

where $A_{\text {dopt }}$ hit is a binary indicator or a count of modern input use (a measure of intensity) at time $t$ for household, $h$, in province $i$. In this study, we focus on modern inputs such as chemical fertilizer (1), Improved seed (2), Herbicide (3) and Pesticide and post-harvest crop protection products (4). The intensity of the adoption of modern inputs ranges from 0 to 4.

The key regressor is $M I$, the market integration, for which, we measured by price dispersion using Eq.(3). More specifically, Eq.(3) is the average price dispersion between the reference market (indexed $r$ ) and prices in the market of the $i^{\text {th }}$ province during the 12 months preceding the cropping season. $P_{i t-1}$ is the average market price in province $i$ at time $t-1$ and $P_{r t-1}$, the average market price in the reference market. We used a log transformation to remove trends in prices induced by a common factor and are naturally interpreted as the percentage price gap. The reference market is the market of the capital city. Furthermore, to capture the temporal dimension of crop market integration, we have substituted price dispersion for the price coefficient of variation (C.O.V) in province $i$ during the 12 months preceding the cropping season in Eq.(2). The coefficient of the C.O.V captures the effect of price volatility on the adoption of yield-increasing inputs. Since our measures of market performance are based on province-level market prices, they are exogenous.

The parameters to be estimated are $\gamma, \theta_{1}, \theta_{2}$, and $\beta$. The parameter of primary interest is $\gamma$ which measures the impact of the output price dispersion (or price volatility) on the use of modern inputs. Province $_{i t-1}$ is a vector of province $i$ characteristics. $W$ and $X$ are vectors of plot and household's socio-demographics characteristics respectively. $u_{i h}$ is the household fixed-effects and $\varepsilon_{i h t}$ the error term. The exogeneity of market performance notwithstanding, we strengthen the identification of parameters in our model using household fixed effects. The potential correlation of $\varepsilon_{\text {int }}$ and household characteristics informs this decision.

\section{Data}

To test our hypothesis, we used data from the Enquête Permanente Agricole (EPA), that is "Continuous Farm Household Survey" of Burkina Faso. We used the five recent rounds of the EPA survey data (that is 2014-2018). The survey is conducted every year by the Ministry of Agriculture and Food Security. EPA sample 4131 in 826 villages across all 45 provinces for the survey aimed at estimating farm input use, production, area, and yield of crops. Market prices ${ }^{1}$ data comes from the market information system of the same ministry. We focus on households who produce cowpea three times or more between 2014 and 2018 and obtain an unbalanced panel of 2448 households. We focus on cowpea which is legume produced in all provinces in Burkina Faso with more than $50 \%$ of the output commercialized (Nikiema and Sakurai, 2020). The description of variables used in the econometric analysis is presented in Table A 1.

\section{Results}

Figure 1 shows the rate of modern inputs use, the price dispersion, and volatility of cowpea at the national level during five consecutive years. Between 2014 and 2018, the price gap between the capital city market and markets in the other provinces has decreased by $51 \%$ while the rate of adoption of modern inputs has increased by $37 \%$. Price volatility seems to be not trending.

\footnotetext{
${ }^{1}$ See Nikiema and Sakurai (2020) for full description of price data used in this study.
} 
We start with the effect of market integration on the decision to use modern inputs. First, columns (1), (2), and (3) of Table 1 show that an increase in price dispersion is significantly associated with a decrease in the probability of using modern inputs. For instance, a $10 \%$ increase in the price gap during the 12 months preceding the planting season lowers the probability to use modern inputs by 0.04 points. Consistent with the conceptual framework, the large price gap between trading markets implies that farmers received lower prices as compared to what they would have received if markets were perfectly integrated; thus, reducing farmers' incentive to invest in yield-increasing inputs.

Second, the column (3), (4), and (5) of Table 1 suggest that price volatility does not significantly affect the decision to use modern inputs. One explanation is that price volatility is likely to follow a seasonal pattern. As a result, farmers may predict price variations such that they only affect their revenue weakly. The result remains consistent when we use the standard deviation as a measure of the price volatility. However, when we interacted price dispersion with high price volatility ${ }^{2}$, the effect becomes significant and stronger (columns (3) of Table 1). This is expected since the effect of weak spatial market integration is compounded by the negative effect of the risk generated by high price volatility. This result remains stable when we set a higher level of cut-offs of price volatility.

Finally, another important question is whether or not a low integration of the crop market discourages previous adopters of modern inputs. For this purpose, we interacted the market integration measures with the lag of the adoption status. The results are shown in columns (2) and (5) of Table 1. As expected, there is a positive association between previous years' adoption status and the current adoption of modern inputs. However, when interacted with high price volatility and price dispersion, the effect becomes significantly negative. This finding is not only consistent with the above results but also suggests that the low output market integration in the previous months before the planting season effect is stronger for previous adopters. Consistent with the conceptual framework, in developing countries, the low integration of the output market is often coupled with a sales slump. As a result, adopters of yield-increasing inputs get discouraged and then dis-adopt even though the use of such inputs increases significantly the yield per ha (Table A 2).

Figure 1. Market integration and modern inputs adoption.

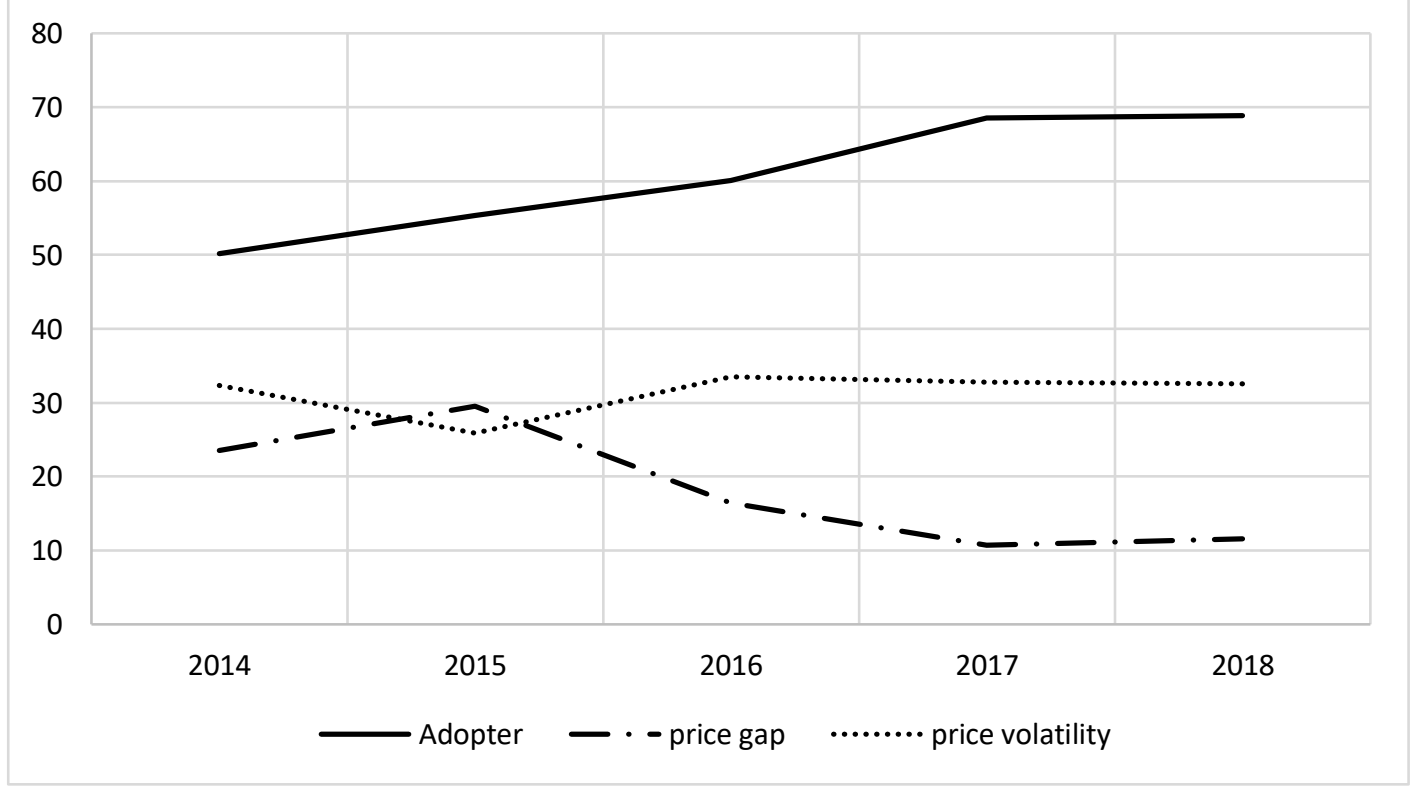

\footnotetext{
${ }^{2}$ High volatility is a dummy variable taking 1 if the coefficient of variation greater than the median value of the C.O.V (about 0.8 ) and 0 otherwise.
} 
Table 1. The effect of commodity market integration on the adoption of modern inputs (Linear probability Household fixed-effects).

\begin{tabular}{|c|c|c|c|c|c|}
\hline Variables & $(\mathbf{1})$ & $(2)$ & (3) & (4) & $(5)$ \\
\hline \multirow[t]{2}{*}{ Price dispersion } & $-0.0054 * * *$ & $-0.004 * * *$ & $-0.004 * * *$ & & \\
\hline & $(0.000)$ & $(0.000)$ & $(0.000)$ & & \\
\hline \multirow[t]{2}{*}{ Price volatility $(C . O . V)$} & & & -0.0007 & -0.0010 & -0.0009 \\
\hline & & & $(0.0011)$ & $(0.0010)$ & $(0.0012)$ \\
\hline \multirow[t]{2}{*}{ Adoption at $t-1$} & $0.181 * * *$ & $0.108 * * *$ & $0.180 * * *$ & $0.185^{* * *}$ & $0.115^{* * *}$ \\
\hline & $(0.002)$ & $(0.001)$ & $(0.004)$ & $(0.004)$ & $(0.008)$ \\
\hline Price dispersion $*$ High volatile & & & $\begin{array}{r}-0.007 * * * \\
(0.000)\end{array}$ & & \\
\hline $\begin{array}{l}\text { Price dispersion } * \text { Adoption at } t \text { - } \\
1\end{array}$ & & $\begin{array}{r}-0.009 * * * \\
(0.000)\end{array}$ & & & \\
\hline High volatile $*$ Adoption at $t-1$ & & & & & $\begin{array}{r}-0.043 * * * \\
(0.004)\end{array}$ \\
\hline \multirow[t]{2}{*}{ Access to transportation } & $0.067 * * *$ & $0.080 * * *$ & $0.077 * * *$ & $0.062 * * *$ & $0.1115 * * *$ \\
\hline & $(0.014)$ & $(0.016)$ & $(0.0161)$ & $(0.014)$ & $(0.0254)$ \\
\hline \multirow[t]{2}{*}{ Use of mobile phone } & 0.021 & 0.023 & 0.0245 & 0.023 & $0.0715^{* *}$ \\
\hline & $(0.018)$ & $(0.020)$ & $(0.020)$ & $(0.018)$ & $(0.031)$ \\
\hline Province covariates & YES & YES & YES & YES & YES \\
\hline Household covariates & YES & YES & YES & YES & YES \\
\hline Plot covariates & YES & YES & YES & YES & YES \\
\hline Year*Region dummy & YES & YES & YES & YES & YES \\
\hline$R$-squared adjusted & 0.170 & 0.175 & 0.218 & 0.158 & 0.161 \\
\hline
\end{tabular}

Notes: $*, * *, * * *$ statistical significance at $10 \%, 5 \%$ and $1 \%$ respectively. Standard errors in parentheses are robust clustered at household level. C. O. V: Coefficient of Variation. High volatile: COV>0.8. For columns (3) and (5) Price volatility is dummy: 1 if C. O. V>0.8. Province characteristics include production shock and average price at the planting season. Number of the observations: 7,829. Number of groups: 2,404 . See Table A 3 and A 4 for full regression outputs.

Now, we turn to the effect of market integration on the intensity of modern inputs adoption. Table 2 shows that the coefficients of both price dispersion and volatility are negative and significant. Consistent with the results in Table 1, columns (1), (2), and (3) of Table 2 suggests that the number of modern inputs used decreases by 0.12 inputs with a $10 \%$ increase in the price gap, which is equivalent to a decrease of $12.5 \%$ approximately relative to the sample mean. In the same line, an increase in price $\mathrm{C}$. $\mathrm{O}$. V by 10 percentage points $(0.1)$ is associated with a decrease in the number of modern inputs used by about 0.0029 , which represents a decrease of $0.3 \%$ relative to the sample mean (column 4 of Table 2). These results suggest that the association between price dispersion and the adoption of modern inputs is stronger.

Lastly, the results in Table 1 and Table 2 show that while access to transportation has a positive and significant effect on both the farmers' decision and intensity to use modern inputs, the use of mobile phone affects only significantly the intensity of adoption of these inputs. However, as it has been shown by Chamberlin and Jayne (2013) different measures of market access may be misleading as they may not reflect the household's actual transaction cost.

The overall results sustain our hypothesis that commodity market integration fundamentally affects the use of modern inputs by farmers in developing countries. The high price gap between producing and consuming locations implies that farmers cannot take full advantage of the price increase in the consuming market. Hence, gain from technology adoption is not efficiently optimized. Our findings are consistent with those of (Porteous, 2020) that is, the use of modern input increases farmer income when markets between producing and consuming locations are well integrated. 
Table 2. The effect of commodity market integration on the intensity of adoption of modern inputs (Household fixed effects).

\begin{tabular}{|c|c|c|c|c|c|}
\hline Variables & $(\mathbf{1})$ & $(2)$ & (3) & $(4)$ & $(5)$ \\
\hline Price dispersion & $\begin{array}{r}-0.012 * * * \\
(0.001)\end{array}$ & $\begin{array}{r}-0.0102 * * * \\
(0.001)\end{array}$ & $\begin{array}{r}-0.0101 * * * \\
(0.001)\end{array}$ & & \\
\hline Price volatility $(C . O . V)$ & & & $\begin{array}{r}-0.0027 * * \\
(0.0013)\end{array}$ & $\begin{array}{r}- \\
0.0029 * * \\
(0.0014)\end{array}$ & $\begin{array}{c}-0.0002 * \\
(0.0001)\end{array}$ \\
\hline Adoption at $t-1$ & $\begin{array}{r}1.0213 * * * \\
(0.000)\end{array}$ & $\begin{array}{r}0.833 * * * \\
(0.000)\end{array}$ & $\begin{array}{r}0.693 * * * \\
(0.004)\end{array}$ & $\begin{array}{r}1.331 * * * \\
(0.0042)\end{array}$ & $\begin{array}{r}0.285 * * * \\
(0.0043)\end{array}$ \\
\hline Price dispersion $*$ High volatile & & & $\begin{array}{r}-0.009 * * * \\
(0.000)\end{array}$ & & \\
\hline $\begin{array}{l}\text { Price dispersion } * \text { Adoption at } t \text { - } \\
1\end{array}$ & & $\begin{array}{r}-0.113 * * * \\
(0.004)\end{array}$ & & & \\
\hline High volatile ${ }^{*}$ Adoption at $t-1$ & & & & & $\begin{array}{r}-0.019 * * * \\
(0.004)\end{array}$ \\
\hline Access to transportation & $\begin{array}{r}0.0014 * * \\
(0.000)\end{array}$ & $\begin{array}{r}0.002 * * * \\
(0.000)\end{array}$ & $\begin{array}{r}0.120 * * * \\
(0.030)\end{array}$ & $\begin{array}{r}0.079 * * * \\
(0.014)\end{array}$ & $\begin{array}{r}0.123 * * * \\
(0.0302)\end{array}$ \\
\hline Use of mobile phone & $\begin{array}{r}0.121 * * * \\
(0.025)\end{array}$ & $\begin{array}{r}0.130 * * * \\
(0.030)\end{array}$ & $\begin{array}{r}0.069 * * \\
(0.036)\end{array}$ & $\begin{array}{r}0.024 \\
(0.020)\end{array}$ & $\begin{array}{r}0.0735^{* *} \\
(0.0365)\end{array}$ \\
\hline Province covariates & YES & YES & YES & YES & YES \\
\hline Household covariates & YES & YES & YES & YES & YES \\
\hline Plot covariates & YES & YES & YES & YES & YES \\
\hline Year*Region dummy & YES & YES & YES & YES & YES \\
\hline$R$-squared adjusted & 0.169 & 0.185 & 0.193 & 0.176 & 0.180 \\
\hline
\end{tabular}

Notes: $*, * * * * *$ statistical significance at $10 \%, 5 \%$ and $1 \%$ respectively. Standard errors in parentheses are robust clustered at household level. C. O. V: Coefficient of Variation. High volatile: COV $>0.8$. For columns (3) and (5) Price volatility is dummy: 1 if C. O. V>0.8. Province characteristics include production shock and average price at the planting season. Number of the observations: 7,829. Number of groups: 2,404. See Table A 3, and A 5 for full regression outputs.

\section{Concluding remarks}

Despite the wide acknowledgment that modern inputs are the key to enhance agricultural productivity in developing countries, the rate of adoption of such inputs remains low. In this study, we have shown that the integration of the crop market affects the use of modern inputs by smallholder farmers. Our results remain robust after controlling for household fixed effects and geographic heterogeneity. Our results imply that in order to succeed, agricultural interventions that target the adoption of modern inputs should be accompanied by market development measures. Physical or economic access to modern inputs may not be enough to stimulate their adoption if the economic return of such inputs is undermined by the lack of crop output market integration. Further investigations, specifically those which are based on general equilibrium modeling may be useful in confirming our findings.

\section{References}

Abdul-Hanan, A. (2016). Does credit market inefficiency affect technology adoption? Evidence from Sub-Saharan Africa. Agricultural Finance Review, 76(4), 494-511. https://doi.org/10.1108/AFR-05-2016-0052

Baquedano, F. G., \& Liefert, W. M. (2014). Market integration and price transmission in consumer 
markets of developing countries. Food Policy, 44, 103-114. https://doi.org/10.1016/j.foodpol.2013.11.001

Barrett, C. B. (2008). Smallholder market participation: Concepts and evidence from eastern and southern Africa. Food Policy, 33(4), 299-317. https://doi.org/10.1016/j.foodpol.2007.10.005

Beaman, L. A., BenYishay, A., Magruder, J., \& Mobarak, A. M. (2018). Can Network TheoryBased Targeting Increase Technology Adoption? SSRN Electronic Journal. https://doi.org/10.2139/ssrn.3225815

Bekkers, E., Brockmeier, M., Francois, J., \& Yang, F. (2017). Local Food Prices and International Price Transmission. World Development, 216-230. https://doi.org/10.1016/j.worlddev.2017.03.008

Burke, M., Falcao Bergquist, L., \& Miguel, E. (2017). Selling low and buying high: An arbitrage puzzle in Kenyan villages. Retrieved https://web.stanford.edu/ mburke/papers/MaizeStorage.pdf

Chamberlin, J., \& Jayne, T. S. (2013). Unpacking the Meaning of "Market Access": Evidence from Rural Kenya. World Development, 41(1), 245-264. https://doi.org/10.1016/j.worlddev.2012.06.004

Cochrane, W. W. (1958). Farm Prices: Myth and Reality. Minneapolis. University of Minnesota Press.

Croppenstedt, A., Demeke, M., \& Meschi, M. M. (2003). Technology adoption in the presence of constraints: The case of fertilizer demand in Ethiopia. Review of Development Economics, 7(1), 58-70. https://doi.org/10.1111/1467-9361.00175

Fackler, P. L., \& Goodwin, B. K. (2001). Chapter 17 Spatial price analysis. Handbook of Agricultural Economics, 1(PART B), 971-1024. https://doi.org/10.1016/S15740072(01)10025-3

Gabre-Madhin, E., Barrett, C. B., \& Dorosch, P. (2003). Technological Change and Price Effects in Agriculture: Conceptual and Comparative Perspectives. IFPRI/MTID Discussion Paper No.62.Washington, D.C.

Hayami, Y., \& Herdt, R. W. (1977). Market price effects of technological change on income distribution in semi-subsistence agriculture. American Journal of Agricultural Economics, 59(2), 245-56.

Judge, G., \& Takayama, T. (1971). Spatial and temporal price allocation models. Journal of International Economics, 3(3), 304. https://doi.org/10.1016/0022-1996(73)90024-X

Karlan, D., Knight, R., \& Udry, C. (2015). Consulting and capital experiments with microenterprise tailors in Ghana. Journal of Economic Behavior and Organization, 118, 281-302. https://doi.org/10.1016/j.jebo.2015.04.005

Michler, J., Tjernstrom, E., Verkaart, S., \& Mausch, K. (2018). Money Matters: The Role of Yields and Profits in Agricultural Technology Adoption. In SSRN. https://doi.org/10.2139/ssrn.3174824

Nikiema, A. R., \& Sakurai, T. (2020). Asymmetry in Transaction Costs and Price Transmission: The Case of Cowpea Market in Burkina Faso. Japanese Journal of Agricultural Economics, 22, 89-94.

Porteous, O. (2020). Trade and agricultural technology adoption: Evidence from Africa. Journal $\begin{array}{llll}\text { of Development } & \text { Economics, } & \text { 144(February } & 2019),\end{array}$ https://doi.org/10.1016/j.jdeveco.2020.102440

Suri, T. (2011). Selection and Comparative Advantage in Technology Adoption. Econometrica, 79(1), 159-209. https://doi.org/10.3982/ECTA7749 


\section{Appendix A}

Table A 1. Descriptive statistics: Market integration and use of modern inputs.

\begin{tabular}{|c|c|c|c|c|}
\hline Variables & Mean & S.D. & Min. & Max. \\
\hline Adopter (=1 if use at least 1 modern inputs) & 0.62 & 0.48 & 0 & 1 \\
\hline Intensity of modern input use & 0.96 & 0.930 & 0 & 4 \\
\hline Yield $(\mathrm{kg} / \mathrm{ha})$ & 768.21 & 410.08 & 0.04 & 4000 \\
\hline $\begin{array}{l}\text { Average Price dispersion (12 months preceding planting sea- } \\
\text { son) }\end{array}$ & 16.71 & 13.48 & 0.09 & 68.05 \\
\hline Price standard deviation & 31.72 & 11.35 & 8.00 & 116.35 \\
\hline Price coefficient of variation $(C . O . V)$ & 0.62 & 1.07 & 0.063 & 2.35 \\
\hline Average Price at planting season (May-July) & 339.07 & 58.06 & 174.83 & 642.36 \\
\hline $\begin{array}{l}\text { Production shock at } t \text {-1(yield deviation from its last } 10 \text { years } \\
\text { trend) }\end{array}$ & 1.46 & 20.61 & -93.39 & 180.05 \\
\hline Access to transportation (=1 if HH has a transportation mean) & 0.50 & 0.50 & 0 & 1 \\
\hline Use of a mobile phone (= 1if HH has a mobile phone) & 0.86 & 0.34 & 0 & 1 \\
\hline Age of the head of the $\mathrm{HH}$ & 43.40 & 14.6 & 18 & 99 \\
\hline Literacy (=1 if HH head has a primary education) & 0.29 & 0.45 & 0 & 1 \\
\hline$O P(=1$ if the $H H$ head is member of farmer organization) & 0.27 & 0.44 & 0 & 1 \\
\hline$A G R(=1$ if HH generate a non-farm income) & 0.954 & 0.21 & 0 & 1 \\
\hline Training (=1 if HH has received agricultural training) & 0.27 & 0.44 & 0 & 1 \\
\hline Credit ( $=1$ if HH has received a credit) & 0.15 & 0.35 & 0 & 1 \\
\hline Working members (the number of active adults in the $\mathrm{HH}$ ) & 5.74 & 3.50 & 1 & 35 \\
\hline TLU (Tropical Livestock Unit) & 1.99 & 5.65 & 0 & 414.54 \\
\hline Crop diversification (number of crops planted) & 3.22 & 1.14 & 1 & 9 \\
\hline Number of plots & 6.19 & 3.99 & 1 & 44 \\
\hline Plot size in ha & 2.98 & 2.603 & 0.005 & 28.57 \\
\hline Plot location (=1 if bush and 0 if near house) & 0.230 & 0.42 & 0 & 1 \\
\hline Plot landscape ( $=1$ if sloped plot and 0 otherwise) & 0.07 & 0.26 & 0 & 1 \\
\hline CES $(=1$ if used soil conservation technologies in the plot) & 0.06 & 0.24 & 0 & 1 \\
\hline Agroforestry (= 1 if agroforestry is practiced in the plot) & 0.68 & 0.46 & 0 & 1 \\
\hline Restored (=1 if the plot is newly restored) & 0.02 & 0.13 & 0 & 1 \\
\hline
\end{tabular}

Note: $\mathbf{H H}=$ household head; C. O. V: Coefficient of variation. Since households have in general more than one plot of cowpea, we only consider the household larger plot. Number of the observations: 7,829. 
Table A 2: The impact of modern inputs adoption on the log of cowpea yield: Household fixed effects.

\begin{tabular}{|c|c|c|}
\hline & $(1)$ & (2) \\
\hline \multicolumn{3}{|l|}{ Variables } \\
\hline \multirow[t]{2}{*}{ Adoption (0/1) } & $0.0788 * * *$ & \\
\hline & $(0.021)$ & \\
\hline \multirow[t]{2}{*}{ Intensity of inputs use (0-4) } & & $0.0436 * * *$ \\
\hline & & $(0.0113)$ \\
\hline \multirow[t]{2}{*}{ Adoption at $t-1$} & 0.001 & 0.002 \\
\hline & $(0.000)$ & $(0.000)$ \\
\hline \multirow{2}{*}{ Province production shock } & 0.000 & 0.0004 \\
\hline & $(0.000)$ & $(0.0005)$ \\
\hline \multirow[t]{2}{*}{ Access to transportation } & 0.020 & 0.0209 \\
\hline & $(0.025)$ & $(14.120)$ \\
\hline \multirow{2}{*}{ Use of mobile phone } & $0.051 *$ & 0.050 \\
\hline & $(0.031)$ & $(0.0312)$ \\
\hline \multirow[t]{2}{*}{ Age of the head } & 0.000 & 0.000 \\
\hline & $(0.000)$ & $(0.000)$ \\
\hline \multirow[t]{2}{*}{ Literacy of the head } & -0.0319 & -0.033 \\
\hline & $(0.021)$ & $(0.0214)$ \\
\hline \multirow[t]{2}{*}{ Membership to $O P$} & $0.047 *$ & $0.0469 *$ \\
\hline & $(0.0271)$ & $(0.0271)$ \\
\hline \multirow[t]{2}{*}{$A G R$} & -0.017 & -0.0139 \\
\hline & $(0.047)$ & $(0.0473)$ \\
\hline \multirow[t]{2}{*}{ Training } & -0.017 & -0.032 \\
\hline & $(0.047)$ & $(0.0249)$ \\
\hline \multirow[t]{2}{*}{ Access to credit } & $0.0302 *$ & $0.0582 *$ \\
\hline & $(0.031)$ & $(0.0315)$ \\
\hline \multirow[t]{2}{*}{ Working members } & $0.008 * * *$ & $0.008 * *$ \\
\hline & $(0.002)$ & $(0.0028)$ \\
\hline \multirow[t]{2}{*}{ Plot size } & $0.087 * * *$ & $0.083 * *$ \\
\hline & $(0.028)$ & $(0.0278)$ \\
\hline \multirow[t]{2}{*}{$T L U$} & 0.002 & 0.002 \\
\hline & $(0.0016)$ & $(0.001)$ \\
\hline \multirow[t]{2}{*}{ Crop diversification } & -0.0104 & -0.0096 \\
\hline & $(0.0108)$ & $(0.0108)$ \\
\hline \multirow[t]{2}{*}{ Number of plots } & $0.006^{*}$ & $0.0063 *$ \\
\hline & $(0.003)$ & $(0.0033)$ \\
\hline \multirow[t]{2}{*}{ Plot location } & 0.000 & -0.0012 \\
\hline & $(0.0238)$ & $(0.0237)$ \\
\hline \multirow[t]{2}{*}{ Plot landscape } & -0.009 & -0.0124 \\
\hline & $(0.0390)$ & $(0.0389)$ \\
\hline \multirow[t]{2}{*}{ Practice of CES } & 0.0198 & 0.019 \\
\hline & $(0.038)$ & $(0.038)$ \\
\hline \multirow[t]{2}{*}{ Agroforestry } & 0.0283 & 0.0281 \\
\hline & $(0.022)$ & $(0.0219)$ \\
\hline \multirow[t]{2}{*}{ Plot newly restored } & -0.029 & -0.029 \\
\hline & $(0.073)$ & $(0.073)$ \\
\hline Year*Region dummy & Yes & Yes \\
\hline$R$-squared adjusted & 0.1060 & 0.1063 \\
\hline
\end{tabular}

Note: $*, * *, * * *$ statistical significance at $10 \%, 5 \%$ and $1 \%$ respectively. Standard errors in parentheses are robust and clustered at household level. Number of the observations: 7,829. Number of groups: 2,404. See table A4.1 for the definition of variables. 
Table A 3. The effect of price dispersion on the use of modern inputs (Household fixed effects).

\begin{tabular}{|c|c|c|c|c|}
\hline \multirow[b]{2}{*}{ Variables } & \multicolumn{2}{|c|}{$\begin{array}{r}\text { Adoption: linear probability } \\
\text { model }\end{array}$} & \multicolumn{2}{|c|}{ Intensity of inputs use } \\
\hline & (1) & (2) & (3) & (4) \\
\hline Price dispersion & $-0.0054 * * *$ & $-0.004 * * *$ & $-0.012 * * *$ & $-0.0102 * * *$ \\
\hline & $(0.000)$ & & & \\
\hline Adoption at $t-1$ & $\begin{array}{r}0.181 * * * \\
(0.002)\end{array}$ & $\begin{array}{r}0.108 * * * \\
(0.0018)\end{array}$ & $\begin{array}{r}1.0213 * * * \\
(0.000)\end{array}$ & $\begin{array}{r}0.833 * * * \\
(0.000)\end{array}$ \\
\hline Price dispersion $*$ Adoption at $t-1$ & & $\begin{array}{r}-0.009 * * * \\
(0.000)\end{array}$ & & $\begin{array}{r}-0.113^{* * *} \\
(0.000)\end{array}$ \\
\hline Planting price & $\begin{array}{r}0.000 \\
(0.000)\end{array}$ & $\begin{array}{r}0.0006 * * * * \\
(0.0002)\end{array}$ & $\begin{array}{r}0.000 \\
(0.000)\end{array}$ & $\begin{array}{r}0.001 \text { *** } \\
(0.000)\end{array}$ \\
\hline Province production shock & $\begin{array}{r}0.000 \\
(0.000)\end{array}$ & $\begin{array}{r}0.000^{* * *} \\
(0.000)\end{array}$ & $\begin{array}{r}0.0014 * * \\
(0.000)\end{array}$ & $\begin{array}{r}0.002 * * * \\
(0.000)\end{array}$ \\
\hline Access to transportation & $\begin{array}{r}0.067 * * * \\
(0.014)\end{array}$ & $\begin{array}{r}0.080 * * * \\
(0.016)\end{array}$ & $\begin{array}{r}0.121 * * * \\
(0.025)\end{array}$ & $\begin{array}{r}0.130 * * * \\
(0.030)\end{array}$ \\
\hline Use of mobile phone & $\begin{array}{r}0.021 \\
(0.018)\end{array}$ & $\begin{array}{r}0.023 \\
(0.020)\end{array}$ & $\begin{array}{r}0.068 * * \\
(0.031)\end{array}$ & $\begin{array}{r}0.073 * * \\
(0.036)\end{array}$ \\
\hline Age of the head & $\begin{array}{r}-0.000 \\
(0.000)\end{array}$ & $\begin{array}{r}0.0002 \\
(0.0004)\end{array}$ & $\begin{array}{r}0.000 \\
(0.000)\end{array}$ & $\begin{array}{r}0.000 \\
(0.000)\end{array}$ \\
\hline Literacy of the head & $\begin{array}{l}0.0127 \\
(0.011)\end{array}$ & $\begin{array}{l}0.0163 \\
(.0139)\end{array}$ & $\begin{array}{r}0.028 \\
(0.022)\end{array}$ & $\begin{array}{r}0.061^{* *} \\
(0.027)\end{array}$ \\
\hline Membership to $O P$ & $\begin{array}{r}0.043 * * * \\
(0.014)\end{array}$ & $\begin{array}{r}.0163 \\
(0.017)\end{array}$ & $\begin{array}{r}0.117 * * * \\
(0.030)\end{array}$ & $\begin{array}{l}0.0401 \\
(0.035)\end{array}$ \\
\hline$A G R$ & $\begin{array}{r}0.0701 * * * \\
(0.025)\end{array}$ & $\begin{array}{r}0.088 * * * \\
(0.028)\end{array}$ & $\begin{array}{l}0.090^{*} \\
(0.046)\end{array}$ & $\begin{array}{l}0.092 * \\
(0.050)\end{array}$ \\
\hline Training & $\begin{array}{r}0.061 * * * \\
(0.013)\end{array}$ & $\begin{array}{r}0.071 * * * \\
(0.016)\end{array}$ & $\begin{array}{r}0.177 * * * \\
(0.030)\end{array}$ & $\begin{array}{r}0.190 * * * \\
(0.036)\end{array}$ \\
\hline Access to credit & $\begin{array}{r}0.032 * * \\
(0.015)\end{array}$ & $\begin{array}{r}0.050 * * * \\
(0.018)\end{array}$ & $\begin{array}{r}0.045 \\
(0.034)\end{array}$ & $\begin{array}{r}0.126 * * * \\
(0.040)\end{array}$ \\
\hline Working members & $\begin{array}{r}-0.001 \\
(0.0015)\end{array}$ & $\begin{array}{r}-0.000 \\
(0.001)\end{array}$ & $\begin{array}{r}-0.004 \\
(0.003)\end{array}$ & $\begin{array}{r}0.000 \\
(0.003)\end{array}$ \\
\hline Plot size & $\begin{array}{r}0.113 * * * \\
(0.015)\end{array}$ & $\begin{array}{r}0.114 * * * \\
(0.018)\end{array}$ & $\begin{array}{r}0.293 * * * \\
(0.036)\end{array}$ & $\begin{array}{r}0.285^{* * *} * \\
(0.039)\end{array}$ \\
\hline$T L U$ & $\begin{array}{r}0.000 \\
(0.000)\end{array}$ & $\begin{array}{r}-0.0001 \\
(0.0008)\end{array}$ & $\begin{array}{r}-0.000 \\
(0.001)\end{array}$ & $\begin{array}{r}-0.0004 \\
(0.001)\end{array}$ \\
\hline Crop diversification & $\begin{array}{r}-0.033^{* * * *} \\
(0.005)\end{array}$ & $\begin{array}{r}-0.025 * * * \\
(0.007)\end{array}$ & $\begin{array}{r}-0.073 * * * \\
(0.010)\end{array}$ & $\begin{array}{r}-0.064 * * * \\
(0.013)\end{array}$ \\
\hline Number of plots & $\begin{array}{r}0.000 \\
(0.001)\end{array}$ & $\begin{array}{r}-0.0016 \\
(0.0021)\end{array}$ & $\begin{array}{r}0.001 \\
(0.003)\end{array}$ & $\begin{array}{r}-0.000 \\
(0.004)\end{array}$ \\
\hline Plot location & $\begin{array}{r}-.00413 * * * \\
(0.0130)\end{array}$ & $\begin{array}{r}-0.048 * * * \\
(0.015)\end{array}$ & $\begin{array}{r}-0.073 * * * \\
(0.024)\end{array}$ & $\begin{array}{r}-0.083 * * * \\
(0.029)\end{array}$ \\
\hline Plot landscape & $\begin{array}{r}0.0149 \\
(0.0193)\end{array}$ & $\begin{array}{l}0.0067 \\
(0.022)\end{array}$ & $\begin{array}{r}0.077 * * \\
(0.039)\end{array}$ & $\begin{array}{l}0.088^{*} \\
(0.045)\end{array}$ \\
\hline Practice of CES & $\begin{array}{r}0.0416^{*} \\
(0.021)\end{array}$ & $\begin{array}{l}0.0410 \\
(0.026)\end{array}$ & $\begin{array}{l}0.074 * \\
(0.042)\end{array}$ & $\begin{array}{r}0.070 \\
(0.049)\end{array}$ \\
\hline Agroforestry & $\begin{array}{r}0.043 * * * \\
(0.012)\end{array}$ & $\begin{array}{r}0.0400 * * * \\
(0.0147)\end{array}$ & $\begin{array}{r}0.087 * * * \\
(0.022)\end{array}$ & $\begin{array}{r}0.076 * * * \\
(0.026)\end{array}$ \\
\hline Plot newly restored & $\begin{array}{r}0.044 \\
(0.039)\end{array}$ & $\begin{array}{r}0.0299 \\
(0.0455)\end{array}$ & $\begin{array}{r}0.098 \\
(0.074)\end{array}$ & $\begin{array}{r}0.053 \\
(0.087)\end{array}$ \\
\hline Year*Region dummy & YES & YES & YES & YES \\
\hline$R$-squared adjusted & 0.170 & 0.175 & 0.169 & 0.185 \\
\hline
\end{tabular}


Table A 4. The effect of price volatility on the adoption of modern inputs (Linear probability household fixed effects).

\begin{tabular}{|c|c|c|c|}
\hline Variables & (1) & $(2)$ & $(3)$ \\
\hline \multirow[t]{2}{*}{ Price volatility (C.O. V) } & -0.0010 & -0.0007 & -0.0009 \\
\hline & $(0.0010)$ & $(0.0011)$ & $(0.0012)$ \\
\hline \multirow[t]{2}{*}{ Price dispersion } & & $-0.004 * * *$ & \\
\hline & & $(0.000)$ & \\
\hline \multirow[t]{2}{*}{ Adoption at $t-1$} & $0.185^{* * *}$ & $0.180 * * *$ & $0.115^{* * *}$ \\
\hline & $(0.004)$ & $(0.004)$ & $(0.008)$ \\
\hline \multirow[t]{2}{*}{ Price dispersion $*$ High price volatility $(C . O . V>0.8)$} & & $-0.007 * * *$ & \\
\hline & & $(0.000)$ & \\
\hline \multirow[t]{2}{*}{ Adoption at $t-1 *$ High price volatility (C. O. V>0.8) } & & & $-0.043 * * *$ \\
\hline & & & $(0.004)$ \\
\hline \multirow[t]{2}{*}{ Planting price } & 0.0002 & $0.001 * * *$ & $0.0007 * *$ \\
\hline & $(0.0001)$ & $(0.0002)$ & $(0.0003)$ \\
\hline \multirow[t]{2}{*}{ Province production shock } & 0.0002 & $0.0011 * * *$ & $0.0014 * *$ \\
\hline & $(0.0003)$ & $(0.000)$ & $(0.0006)$ \\
\hline \multirow[t]{2}{*}{ Access to transportation } & $0.062 * * *$ & $0.077 * * *$ & $0.1115^{* * *}$ \\
\hline & $(0.014)$ & $(0.0161)$ & $(0.0254)$ \\
\hline \multirow[t]{2}{*}{ Use of mobile phone } & 0.023 & 0.0245 & $0.0715 * *$ \\
\hline & $(0.018)$ & $(0.020)$ & $(0.031)$ \\
\hline \multirow[t]{2}{*}{ Age of the head } & $0.000^{*}$ & 0.0004 & -0.0002 \\
\hline & $(0.000)$ & $(0.0004)$ & $(0.0006)$ \\
\hline \multirow[t]{2}{*}{ Literacy of the head } & 0.0135 & 0.017 & 0.029 \\
\hline & $(0.011)$ & $(0.013)$ & $(0.022)$ \\
\hline \multirow[t]{2}{*}{ Membership to $O P$} & $0.045^{* * *}$ & 0.0165 & $0.122 * * *$ \\
\hline & $(0.0145)$ & $(0.0176)$ & $(0.0305)$ \\
\hline \multirow[t]{2}{*}{$A G R$} & $0.073 * * *$ & $0.088 * * *$ & $0.097 * *$ \\
\hline & $(0.025)$ & $(0.0287)$ & $(0.046)$ \\
\hline \multirow[t]{2}{*}{ Training } & $0.059 * * *$ & $0.0712 * * *$ & $0.174 * * *$ \\
\hline & $(0.013)$ & $(0.0166)$ & $(0.030)$ \\
\hline \multirow[t]{2}{*}{ Access to credit } & $0.0385^{* *}$ & $0.0539 * * *$ & $0.059 *$ \\
\hline & $(0.015)$ & $(0.0189)$ & $(0.034)$ \\
\hline \multirow[t]{2}{*}{ Working members } & -0.001 & -0.000 & -0.005 \\
\hline & $(0.0015)$ & $(0.0018)$ & $(0.003)$ \\
\hline \multirow[t]{2}{*}{ Plot size } & $0.1142 * * *$ & $0.1147 * * *$ & $0.295 * * *$ \\
\hline & $(0.016)$ & $(0.0180)$ & $(0.037)$ \\
\hline \multirow[t]{2}{*}{$T L U$} & 0.0001 & -0.0001 & -0.0002 \\
\hline & $(0.000)$ & $(0.000)$ & $(0.001)$ \\
\hline \multirow[t]{2}{*}{ Crop diversification } & $-0.034 * * *$ & $-0.0256 * * *$ & $-0.076 * * *$ \\
\hline & $(0.006)$ & $(0.0072)$ & $(0.0109)$ \\
\hline \multirow[t]{2}{*}{ Number of plots } & 0.001 & -0.0013 & 0.0034 \\
\hline & $(0.001)$ & $(0.0021)$ & $(0.0032)$ \\
\hline \multirow[t]{2}{*}{ Plot location } & $-0.0398 * * *$ & $-0.048 * * *$ & $-0.070 * * *$ \\
\hline & $(0.013)$ & $(0.0155)$ & $(0.0245)$ \\
\hline Plot landscape & 0.0209 & 0.009 & $0.092 * *$ \\
\hline & $(0.019)$ & $(0.0221)$ & $(0.039)$ \\
\hline Practice of CES & $0.043 * *$ & 0.0429 & $0.0781 *$ \\
\hline & $(0.022)$ & $(0.026)$ & $(0.042)$ \\
\hline Agroforestry & $0.042 * * *$ & $0.039 * * *$ & $0.085 * * *$ \\
\hline & $(0.012)$ & $(0.0147)$ & $(0.0226)$ \\
\hline Plot newly restored & 0.048 & 0.029 & 0.1077 \\
\hline & $(0.039)$ & $(0.045)$ & $(0.0757)$ \\
\hline Year*Region dummy & YES & YES & YES \\
\hline$R$-squared adjusted & 0.158 & 0.218 & 0.161 \\
\hline
\end{tabular}

Note: $*, * *, * * *$ statistical significance at $10 \%, 5 \%$ and $1 \%$ respectively. Standard errors in parentheses are robust and clustered at household level. Number of the observations: 7,829. Number of groups: 2,404. See table A4.1 for the definition of variables. C. O. V: Coefficient of Variation 
Table A 5. The effect of price volatility on the intensity of adoption of modern inputs (household fixed effects).

\begin{tabular}{|c|c|c|c|}
\hline Variables & (1) & $(2)$ & 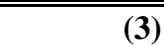 \\
\hline \multirow[t]{2}{*}{ High Price volatility $(C . O . V)$} & $-0.0027 * *$ & $-0.0029 * *$ & $-0.0002 *$ \\
\hline & $(0.0013)$ & $(0.0014)$ & $(0.0001)$ \\
\hline \multirow[t]{2}{*}{ Price dispersion } & & $-0.0101 * * *$ & \\
\hline & & $(0.001)$ & \\
\hline \multirow[t]{2}{*}{ Adoption at $t-1$} & $1.331 * * *$ & $0.218 * * *$ & $0.285^{* * *}$ \\
\hline & $(0.0042)$ & $(0.003)$ & $(0.0043)$ \\
\hline \multirow{2}{*}{ Price dispersion $*$ High Price Volatility (C. O. V>0.8) } & & $-0.009 * * *$ & \\
\hline & & $(0.000)$ & \\
\hline \multirow[t]{2}{*}{ Adoption at $t-1 *$ High Price Volatility (C. O. V>0.8) } & & & $-0.019 * * *$ \\
\hline & & & $(0.004)$ \\
\hline \multirow[t]{2}{*}{ Planting price } & $0.0004 * * *$ & & $0.0022 * * *$ \\
\hline & $(0.0002)$ & & $(0.0004)$ \\
\hline \multirow[t]{2}{*}{ Province production shock } & $0.000 * *$ & $0.000 * * *$ & $0.002 * * *$ \\
\hline & $(0.000)$ & $(0.000)$ & $(0.0007)$ \\
\hline \multirow[t]{2}{*}{ Access to transportation } & $0.079 * * *$ & $0.120 * * *$ & $0.123^{* * *}$ \\
\hline & $(0.014)$ & $(0.030)$ & $(0.0302)$ \\
\hline \multirow[t]{2}{*}{ Use of mobile phone } & 0.024 & $0.069 * *$ & $0.0735 * *$ \\
\hline & $(0.020)$ & $(0.036)$ & $(0.0365)$ \\
\hline \multirow[t]{2}{*}{ Age of the head } & 0.0002 & 0.000 & 0.0004 \\
\hline & $(0.000)$ & $(0.000)$ & $(0.0004)$ \\
\hline \multirow[t]{2}{*}{ Literacy of the head } & 0.0163 & $0.061 * *$ & $0.063 * *$ \\
\hline & $(0.014)$ & $(0.027)$ & $(0.0275)$ \\
\hline \multirow[t]{2}{*}{ Membership to $O P$} & 0.0163 & 0.0401 & 0.0394 \\
\hline & $(0.017)$ & $(0.035)$ & $(0.0394)$ \\
\hline \multirow[t]{2}{*}{$A G R$} & $0.086^{* * *}$ & $0.089 *$ & $0.093 *$ \\
\hline & $(0.028)$ & $(0.050)$ & $(0.050)$ \\
\hline \multirow[t]{2}{*}{ Training } & $0.070 * * *$ & $0.191 * * *$ & $0.191 * * *$ \\
\hline & $(0.016)$ & $(0.036)$ & $(0.0361)$ \\
\hline \multirow[t]{2}{*}{ Access to credit } & $0.048 * * *$ & $0.126 * * *$ & $0.134 * * *$ \\
\hline & $(0.018)$ & $(0.035)$ & $(0.040)$ \\
\hline \multirow[t]{2}{*}{ Working members } & 0.000 & 0.000 & 0.0001 \\
\hline & $(0.001)$ & $(0.003)$ & $(0.003)$ \\
\hline \multirow[t]{2}{*}{ Plot size } & $0.112 * * *$ & $0.282 * * *$ & $0.2843 * * *$ \\
\hline & $(0.018)$ & $(0.039)$ & $(0.0391)$ \\
\hline \multirow[t]{2}{*}{$T L U$} & 0.000 & 0.000 & -0.0003 \\
\hline & $(0.000)$ & $(0.001)$ & $(0.0010)$ \\
\hline \multirow[t]{2}{*}{ Crop diversification } & $-0.025 * * *$ & $-0.064 * * *$ & $-0.064 * * *$ \\
\hline & $(0.007)$ & $(0.013)$ & $(0.0138)$ \\
\hline \multirow[t]{2}{*}{ Number of plots } & -0.001 & -0.000 & 0.0002 \\
\hline & $(0.0021)$ & $(0.004)$ & $(0.0041)$ \\
\hline \multirow[t]{2}{*}{ Plot location } & $-0.032 * * *$ & $-0.081 * * *$ & $-0.0820 * * *$ \\
\hline & $(0.015)$ & $(0.030)$ & $(0.0295)$ \\
\hline Plot landscape & 0.0055 & $0.072 *$ & $0.097 * *$ \\
\hline & $(0.022)$ & $(0.045)$ & $(0.0457)$ \\
\hline Practice of CES & 0.0410 & 0.070 & 0.0749 \\
\hline & $(0.026)$ & $(0.049)$ & $(0.0504)$ \\
\hline Agroforestry & $0.040 * * *$ & $0.075 * * *$ & $0.0762 * * *$ \\
\hline & $(0.014)$ & $(0.026)$ & $(0.026)$ \\
\hline Plot newly restored & 0.032 & 0.051 & 0.0536 \\
\hline & $(0.045)$ & $(0.087)$ & $(0.089)$ \\
\hline Year*Region dummy & YES & YES & YES \\
\hline$R$-squared adjusted & 0.193 & 0.176 & 0.180 \\
\hline
\end{tabular}

Note: $*, * *, * * *$ statistical significance at $10 \%, 5 \%$ and $1 \%$ respectively. Standard errors in parentheses are robust and clustered at household level. Number of the observations: 7,829. Number of groups: 2,404. See table A.1 for the definition of variables. Cov: Coefficients of variation 